\title{
Ritual Performative Ceremonies and Values in the African Context
}

\author{
Dr. Samuel Manaseh Yirenkyi \\ Department of Theatre Arts, University of Education, Winneba, Ghana
}

\begin{abstract}
This paper discusses and examines performative ritual ceremonies and their values in the African cultural context. Ritual performative ceremonies play a key role in interpreting and understanding the African communal value systems. The various rituals and ceremonies in the African communal systems serve as a bond that keeps the people together and provide a kind of standardized way of living. African communities are not complete without the presence of a supreme being and lesser gods. Rituals emphasises the place and importance of the Supreme Being and the lesser gods in the community. Ceremonies also are placed in value as they tend to give the communities some sort of hope and serve as a reminder of their past, their present and the future they look forward to. Ceremonies in the African communal system are the very core foundations on which togetherness are built on. An individual cannot make up a community and in such case, an individual cannot commemorate a ceremony. It is a collective work of a community. Ceremonies from time to time, create an avenue through which community members come together to foster and promote growth and development. Ceremonies also give the people of sense of importance of living. Funerals for example, remind people of the essence of living a good and fulfilled life.In the African setting, rituals and ceremonies are interconnected. Even though they can be treated as separate entities, the importance of their interdependency is key in the African system. Rituals are ceremonies and ceremonies contain rituals. The purpose of this study was to examine rituals and ceremonies, their values and the point of convergence. The scope of this study will be limited to performative rituals ceremonies in some African societies.
\end{abstract}

Keywords:Rituals, ritual, performance, performative, ceremonies, communal, values, development, interdependency, African context, standardization

DOI: $10.7176 / \mathrm{JAAS} / 57-04$

Publication date: August $31^{\text {st }} 2019$

\section{Introduction}

The African communal system features the key elements of interdependency and correlation living. It is imperative to note that the identity of the African lies within their communal nature, which sums up their way of life. The system features other elements that thrive on interdependency. Take away interdependency and the core foundations of the African communal system are broken. The essence of the communal system in Africa is an issue espoused by many authors. Agulana, (2010) looked at communalism as the sense of awareness which identifies an individual not as an isolated character, but as an entity whose being and survival is consequent upon its union with other human beings within an identified locality. The imperativeness of this assertion captures the value of communalism, as simply put, people rely on other people for their survival.

The formation of human institutions cannot be complete without the presence of values. Every society needs some form of values to form the core of the various corrective and motivational institutions that guide the daily activities for the people. Individuals, families and societies at large have principles and standards which are commonly held by societies, they are termed social values. Social values then refer to the ideas shared by members of a society as to what is good, right, and necessary. According to Ogbujah, (2014) since societies are not identical with each other, social values thus, are different from society to society and could change from time to time due to influences from other cultures, termed as acculturation. The values of some African communities remain unchanged while some communities have completely lost their values, due to influence and adulteration from other cultures.

African traditional values would refer to the social principles that are indigenous to African people, which have either enhanced or hindered inter- communal relations. The values of a society are significant because they determine the contents of the norms, which help in maintaining social order. Each value has a conforming norm, or put differently, all norms express social values. Thus, the values which are more difficult to identify because of their abstract nature are more easily inferred from social norms exhibited in actual everyday behaviours. The mention of values in the African communities would not be complete without mentioning the place of rituals and ceremonies.

The question of what is a community, what are the key features of a community and how communal living impacts on the lives of individuals in an area that has drawn wide discussions from philosophers. The cynics' philosophers in ancient Greece belonged to the school of thought that communal system of living should be abolished as it prevented humans from living a life of innocence. The view of this group of individuals has 
however been debunked by a top hierarchy of philosophers such as Socrates, Plato, and Aristotle, to mention but a few who have emphasized the value and importance of a community. Community, many great thinkers remind us, is a necessary condition for the realization of human social goals. The communal system of living births the presence of values which are essential to the positive realization of the hopes and aspirations of a people. These values are enshrined and upheld in the various rituals and ceremonies which serve as a reminder of the essence of living together. The place of rituals and ceremonies cannot be overlooked in communal system of living.

Culture distinguishes a people from each other as trumpeted by Aziza (2001) who posited that:

Culture refers to the totality of the pattern of behaviour of a group people. It includes everything that makes them distinct from any other group of people for instance. Their greeting habits, dressing, social norms and taboos, food, songs and dance patterns, rites of passage from birth, through marriage to death, traditional occupations, religious as well as philosophical beliefs.

Culture is said to be passed on from generation to generation. The acquisition of any cultural trait is as a result of the nature of socialisation process as posited by Fafunwa, (1974):

The child grows into and within the cultural heritage of his people. He imbibes it, Culture, in traditional society is not taught. The child observes, imbibes and mimics the action of his elders and siblings. He watches the naming ceremonies, religious services, marriage rituals, funeral obsequies. He witnesses the coronation of a king or chief, the annual yam festivals, the annual dance and acrobatic displays of guilds and age groups or his relations in the activities, the child in a traditional society cannot escape his cultural and physical environments.

The above positions as explained showed us that, every human being grows up in a particular geographical area or community and that person is likely to become imbued with the culture of that community whether knowingly or unknowingly during the process of his or her social interaction. In fact, Etuk (2003) is of the opinion that: an entire way of life would embody, among other things, what the people think of themselves and the universe in which they live. In other words, how the people in that particular geographical way organises themselves and their lives in order to ensure survival. One can safely therefore say that, there can be no culture without a society. It can also be said that, the culture of a people is uniquely human centred and shared among the people and with other people in a society. A culture may be said to selective in that it absorbs and accepts from other cultures of a particular group of people.

The communities that every individual lives have daily ways of forcing and placing values on the individual about what that particular cultural group accepts as bad or good. Every human being go on his daily life trying to conform to the immediate acceptable ways of behaviour and conduct. People who do not conform to societal norms and values are sometimes called to order by the members of the society. African culture with particular reference to some communities like the Akans of Ghana for instance has no room for theft, rape, murderer and adultery. A thief once convicted may be exposed in broad daylight to the whole community and be made to carry the object he or she stole and paraded through the community, sometimes stripped naked and whipped. A rapist may suffer and go through the same ordeal and to some extent may be banished from the community entirely. An adulterer is not spared either. Communities in Akan societies shun this type of crimes. The sense of personal shame and the disgrace the adulterer, thief, murderer or the rapist has brought on himself or herself, family, relations and friends would be more than enough to serve as a deterrent to the most daring criminal. Antik (2002) has posited that, what a people hold to be true, right or proper with regards to those things that explains much of the cultural traits by which they become identified, what Antiak called traits which can as well be treated as values. Etuk (2002) further advanced the argument and stressed that no group of people can survive without a set of values and code of ethics which holds them together and guarantees their continued existence.

\section{Rituals, Ceremonies and their values}

Rituals can be defined as a religious activity that involves actions that are performed in a coherent manner. Rituals can also be looked at as something that is done regularly and becomes a part of the daily life of an individual. Rappaport (1999) defined ritual as:

The performances are more or less invariant sequences of formal acts and utterances not entirely encoded by the performers. This definition, being extremely terse, demands elaboration and discussion. Before discussing its specific features (performance, formality, invariance, inclusion, of both acts and utterances, encoding by other than the performers) several general comments are in order.

Religion is the broad scope under which rituals come under. Rituals and religion cannot be separated. Kyalo (2013) stated that ritual is the very heart and soul of religion and that ritual must be viewed as both prior to and more fundamental than either myth or doctrine. Every community has a kind of religious system which features various rituals. Adebolu (2016) defined religion as a unified system of beliefs and practices relative to sacred things, that is, to things set apart and forbidden, beliefs and practices which guide the way of life of a people The place of rituals in the society is to remind the people of the existence and importance of the supreme being and other deities. It also constantly checks the standard of living in the community. Rituals can or may be used to 
signify the commencement and the end of the life cycles, which are attributed to the supernatural.

In order to know and appreciate the value of rituals it is important to look at the classification of rituals. Rituals, according to Turner (1973) can be classified under seasonal, contingent, and affliction. Seasonal rituals represent the various activities of words performed and recited or chanted before the commencement of culturally defined moment of change form one season to the other, example from rainy season to dry season. Contingent rituals are rituals held in response to an individual or collective situation or crisis. Contingent rituals feature acts performed in response to the transition from one life stage to another or a response to a crisis such as marriage, death, birth, puberty among others. Affliction rituals are also performed to exercise evil spirits that bring affliction on people and also to pacify the gods on behalf of those who go contrary to the decrees of the gods and are punished as a consequence.

The value of rituals cannot be overlooked in a community. Rituals mark out the very important aspects of our everyday lives. The commencement of life, the beginning of a new season, the initiation from one stage to another, healing, pacification, punishment among others are all done through rituals. The survival of every community depends on the level of attention paid to the various rituals. For example, if a community is supposed to perform a ritual to mark the commencement of the rainy season a planting for a farming season, celebrations of important events such as hooting at evil occurrences, marking important events in a communityand they refuse to do so, they may incur the wrath of the gods which may elude them of their harvest, eventually resulting in starvation and famine

Ceremonies are acts that are set by traditions and customs to usually commemorate an important event in the life of group of people. Ceremonies usually have a laid down format and are performed in a formal way. Ceremonies often features various values that are important in the life of a group of people.

In Africa, ceremonies usually mark important events. They remind the people of the importance of their existence. Ceremonies mark the passage of time and the sharing of values and traditions across generations. Although ceremonies differ across various cultures, it is imperative to note that every culture has its own form of ceremonies. Ceremonies serve as a means of cultural preservation and a channel through which traditions and customs can be passed on from generation to generation.

Ceremonies mark the very important stages in the transition of an individual from one stage to another. According to Manu (2003), there are some major African initiation rites, marked by ceremonies which are the core of human growth and development. Birth, death, marriage, puberty, communal growth, harvest, seasonal change among others are all marked by ceremonies that encompasses the importance and value of these events in the lives of individuals. Ceremonies link an individual to a community, and the community to a larger spiritual world. The place of ceremonies cannot be avoided in the African setting. Ceremonies contain the various elements that make life complete. For example, a new born baby is introduced to the community and the world at large through a naming ceremony. This ceremony is the stage where the child is given an identity and is recognized by the world.

\section{The Convergence: Rituals and Ceremonies}

All the various stages of remarkable events in the lives of various communities, there are various ceremonies, full of rituals that commemorate such events. In an attempt to jointly define ritual and ceremonies, the researcher identified an assertion made by Kyalo (2013) in his study which partly looked at the meaning or meanings of ritual in African cosmology. He posits that:

Rituals are symbolic, routine, and repetitive activities and actions through which we make connections with what we consider to be the most valuable dimension of life. They are often associated with a significant events or places in our individual and communal lives. Rituals set aside specific times and places and provide us opportunity to ponder their meaning and to connect emotionally.

Rituals and ceremonies are keen in the life of a community. They provide the means through which the individuals in the various communities can bond with each other and also a means by which various communities bond with each other. As defined above, ceremonies are acts that are set by traditions and customs to usually commemorate an important event in the life of the group of people. The place of rituals in ceremonies is tantamount to achieving the intent behind the ceremonies. In executing a naming ceremony, a means through which a child is given an identity, the ritual of making libation on behalf of the child to the gods opines a sense of security and protection for the child throughout his life. The genesis of the child's life is secured as it is believed that the child is connected with the spirit world and has been recognized as part of the family.

A ritual is a patterned enactment involving the performance during occasions not giving over to daily and technical routine, of specific symbolic behaviours and the manipulation of sacred objects all of which are innately related to the society's beliefs about or its relationship with the cosmos (Bourgault, 1998). The performance of rituals are said to strengthen social solidarity by remaining and reminding performers of their place in the cosmos, their connection with eth universal forces and their lives and ties with one another. Thus, in the view of Bourgalt (1998), in traditional agrarian societies, the important rituals are sacred ones because they 
along with myth are the dominant means through which the group may be able to articulate its relationship with the universe. They may be useful they articulate in a dramatic way the social relevance of, and organisation of the community. Rituals are useful because through their enactment is demonstrated vividly the place of everyone in a traditional community. As (reference) noted, Africans are necked deep in ritual because it provides them a useful structure to help them what is going on around them and how to get into it. Social change is strengthened through the re-enactment of seasonal rituals in traditional communities because their social order present in the ritual form is made to be immutable. The performance of rituals presents the world in the only way that it can be. Sacred rituals are inclusive of performative frameworks which help humankind to cope with life's cyclical periods: birth, puberty, marriage, parenthood, social advancement, occupational advancement and death. They also include the various celebrations of the passing of seasons as happens with seasonal ritual activities associated with ceremonies against sickness, infertility and crisis rituals whose enactments maybe used to empower or strengthen warring factions or to reunite warring groups or factions and hardships in seasons or drought. These rituals when taking together represent the cycle of life which is by definition sacred in its orientation tied to the relationship between humans and their ancestors and the lesser gods (Sieber, 1987).

In the enactment of rituals, the conflicts of a society are worked out or at least made palatable to the members of the group in the face of the broader sense of existence. Rituals also provides model for social action which takes into account, and gives equal weight to "logico- meaningful structures and causal-functional structures in society and elaborates on the inherent differences in integration between these two systems of social function Geetz (1973). Rituals also have a function to play in the potential leading to social change. Societies experience rapid growth economically, socially and or politically and as such may experience or are likely to experience difficulties in the cultural set up and the structures which will provide meaning to people becoming detached from segments of the social group. The performance of rituals must however occur in a place separated symbolically from ordinary technical, day to day existence. This separation from mundane existence occurs through what Turner (1982) termed ritual framing. In her view, framing separated the "the indicative mood" or daily life from "the subjunctive" or the period of ritual enactment. This framing is usually accomplished through an act that clearly demarcates sacred space time from mundane space time(Turner and Turner, 1988)

Rituals again may refer to an event or performance often associated with the sacred, which is distinguished from ordinary day to day life by the use of special language, music or dance. Rituals are organized around critical junctures that is or occasions where societies may be disrupted, like childbirth, death and marriage and where outcomes are unclear. They constitute events which help people over dangerous period $\mathrm{s}$ of their lives (Awedoba, 2005)

Rituals are a form of communication. It is a powerful means of communicating emotions and involves the use of formulaic or stylized speech and repetitions, but a repetition very different from that of ordinary habitual actions. Language has the capacity for communicating an indefinite range of ideas, but ritual does not. What ritual, in its stylized form communicates are important central themes of the culture of the community.

Ritual events in small societies which are the traditional focus of anthropologist involve entire communities. These rituals or ceremonies have kingship, economic, religious, political and aesthetic dimensions. Adams and Goldbard, (2002) saw rituals as symbolic action. To them, a ritual is an enactment of ideals, values and expectations, serving as a bridge between the level of ideals and the levels of the day to day life of the people. Rituals usually involve the union of speech and patterned behaviour which has the capacity to change the emotional states of the participants.

From the above discussion, rituals may be viewed as a daily repetitive occurrence involving the use of speech and body language. Some of the rituals are mimed, though many others combine music and dialogue to appeal to the emotional and faculty of the on-lookers as well as the performers. Rituals are important to African indigenous religions. Rituals are cultural or religious ceremonies that celebrate or commemorate specific events that have deep religious significance. Rituals serve to reinforce importance religious beliefs through meaningful activities that comfort or joy and thus strengthens the unityof the followers of the religious tradition. They are often associated with important human activities or events such as planting and harvesting. The performances of ritual acts are done for special purposes inclusive of thanksgiving, rites of passage, appeasement, and divination and sometimes with the special request of ancestral spirits. It is noticed that the idea of ritual performance can emanate from either the living or the spirits or ancestors. Rituals are therefore, a means of worship which asserts the spirits awareness of the living and their needs. It also strengthens the relationships between the living and the spirit world. By rituals the paranormal commune with mortals. Rituals reveal values at deepest level, men express in the ritual what moves them most and since the form of expression is conventional and obligatory, it is the values of the group that are revealed. The writer therefore sees in the study of rituals, the key understanding of the essential constitution of human existence. The performance of ritual is a means by which people express their values and make a statement about who they are and their way of life. The conventional nature is expressed for example in dipo puberty rites of the Krobo people of the eastern region of Ghana. The dipo performance is a reflection of the traditional krobo way of life and is obligatory in the sense that, it is expected of every female 
member in the community. The rite of passage which involves initiation rites may include incisions on the body, test of endurance, genital cutting and among others, but for females the emphasis is on fertility. Amponsah, (1997) believed that, these celebrations are necessary for ensuring the propagation of a lineage and providing status. They also help determine family organisation domestic hierarchies and future lineage relationships. This expresses how the individual who goes through the rites of passage gains a definite place in the lineage as a mature person and gains status as a member of the tribe or group. Cultural identity here is therefore, of major importance which includes education on issues such as marriage, sex, child bearing, funeral and burial rites and domestic skills which are stressed in the case of females as it is a major criterion for marriage.

\section{Essence of Rituals and Ceremonies}

Rituals and ceremonies play very important roles in the life of a community. Rituals and ceremonies offer us a confined space and time in which we can capitalize on to commemorate our past, to become aware of our present, and to visualize our future. The presence of rituals and ceremonies in a community mark the establishment of the presence of values, a sense of communalism, a sense of respect for authorities and elders and a sense of timing.

The presence of values in a society is necessary in the physical, spiritual and emotional wellbeing of a community. The values guide the people of a community as to how they should lead their lives. The various values which can be categorized under moral, political, religious, social among others are all established through rituals and ceremonies. When an act is performed constantly in a community and becomes part of the life of the people, it eventually becomes a societal value, which is the ideal shared by a society as to what is good and right. Rituals and ceremonies attach the element of the supernatural. They are very formal in nature with a structured and organised manner of executing the various patterns and the people revere them. Whereas there is no ritual without formality all that is formal is not ritual (Rappaport 1999). The Aboakyer festival of the people of Effutu in Winneba Ghana in can be cited as an example. On the Friday of the festival week, the gods are carried through the principal streets of the town. This ritual is there to serve as a reminder to the people of the presence and superiority of the gods, denoting the element of the supernatural.

Establishing a sense of communalism is also one important factor that rituals and ceremonies provide us. The communal nature of Africans cannot be overlooked. The nature of rituals and ceremonies are participatory. They require the participation of all community members, although some rituals are reserved for a particular group of people in the community, they still require the backing and support of the entire community. A divided community cannot progress effectively as Sarpong, (2003) captured the importance of participation as: "participation continues to play a central role in economic, social and political developments of both traditional and modern societies". The role of participation in communalism is enshrined in the various rituals and ceremonies. A naming ceremony for instance, provides a medium through which all members of a community gather to welcome a child and give the child an identity. The child's moral upbringing then becomes a responsibility of the entire community. The presence of the community members serves as a witness to the entire ritual process to affirm that indeed the child has been accepted into the society.

Rituals and values also create a sense of respect for authority and elders in the community. The presence of various authorities is needed in order for a community to develop and progress efficiently. The role family heads, community gate keepers, elders and chiefs are important and must be identified in a community to establish authority. It is believed that the authorities of a community are the custodians who hold the traditions, norms and values as well as the heritage of the community. There are certain rituals that are reserved for certain elderly people in the community. Festivals for instance require the presence of a chief and various community elders before they can be executed adequately. The Chief Priest for instance in the African traditional setting, is seen as a figure of authority in the community, who serves as an intermediary between the people and the gods. Adebolu (2016) posited the role of the chief priest in his attempt to explore various death rituals performed among some clans in Nigeria. He stated that

the priest in African traditional religion acts as intermediary between God and the people and also leads them in worship as done in other religions.

The role of the chief priest is key in rituals and ceremonies. He acts as a link between the people and the gods and since the various rituals and ceremonies contain the element of the supernatural, the chief priest is revered in the community because of his primary function as the link between the mortal and the spirit world. Rituals and values usually are historic and are at the centre of this transmission because they have the experience and knowledge and are therefore respected in the society. The means of burying the dead and the importance attached to all the ritual activities is also a means through which the elderly can be respected in the society. Some communities only recognize the death of the aged as natural. The rite of burial among the Emure people accentuates the stage and status of the dead in terms of age. The approved age for any burial ceremony begins at age sixty (60) (Adebolu, 2016). This draws respect for the aged in society as it is believed that they have lived good lives and also encourages the young to strive and live good lives in order to grow old, become revered in the community. 
The sense if timing is also a key feature in the African setting. Timing in the African setting goes beyond the mere lunar dates and calendars. The passage of timing in the African setting can be represented by the change in season, the death of an individual or the birth of a baby among others. Mbiti (1990) as cited by Ogbujah (2014) made an argument of what time is to the African:

The question of time is of little or no academic concern to African people in their traditional life. For them, time is simply a composition of events which have occurred: which are immediately to occur. The most significant consequence of this is that, according to traditional concepts, time is twodimensional phenomenon, with a long past, a present and virtually no future. The linear concept of time in Western thought, with an infinite future, is practically foreign to African thinking.

The argument tried to examine what time means in the African setting. Rituals and ceremonies mark certain important events in the life of a community or the individual. The enacting of these rituals and ceremonies are key in identifying the passage of time in a community. Without the presence of rituals and ceremonies, the African would lose the sense of timing. The traditional concept of time marks and past and present, which guides the people to examine their past and juxtapose with their current lives, which serves as a kind of a correctional institution that aids them to check and do away with the ills in the society. Rituals and ceremonies are the best mediums to identify time in the African society. A funeral ceremony for instance in the Akan setting of Ghana highlights the passage of time, as it denotes the transition from one stage of life to another. The funeral ceremony features a period where the people are reminded that each person will come to a time in his life where he will have to cross over to another life. The sense of timing is imperative as it guides the daily lives of individuals and the community at large.

Culture is said to be an epitome of different values which are closely related with each other. One cannot meaningfully comment on community culture and forget about the moral, social political, religious and more importantly the economic values imbedded and how they manifest in An African traditional cultural activities or performances and the importance attached to these values.

Social values of a culture are seen to be those of the beliefs and practices that are associated with that particular group in a geographical area. That society may have a way of directing the beliefs and practices that are performed by its members whenever and wherever the occasion demands. For example, we have games, festivals, taboo and sacrifice, and music and dances that reserved for particular and different communities. These performative activities are performed by the particular societybecause they see it as being important and of high value. African cultures cannot separate social values from religious, moral, political and economic values. Africans in some traditional festivals like the Odwira of the people of Akuapemin Ghanawhich has religious undertones, the festival ends up with sacrifices that were offered to certain deities on special days so as to attract abundant blessings on to the members of the community. Social values are claimed to be linked to customary laws of the community. They may comprise of the traditional pomp and pageantry of festive occasions that a community of liked and same minds see as important for their survival. The outdooring and the eating of new yam in some Akan communities, the hooting of hunger in some Ga communities and the introduction and eating of new maize in some northern communities in Ghana has a way of encouraging hard work and checking drought or famine. The ritual performative festivals helps to discipline communities to be law abiding not to do anything when the time and season is not due. Festivals are celebrated in order to bring together members of a town or village who have travelled from their places of abode to come back and reunite with the families back at home. Most indigenes use the occasion as an opportunity to find life partners. They also use the occasion as to reconcile differences, quarrels and disputes among groups or individuals. Gyekye, (2005) is of the opinion that, the collective roles of festivals are directly connected to values that a community looks upon as vital to its ideology, such as social identity, historical continuity and physical survival. It is seen that festivals develop around the marking of unique occasions and around the festivity of important events. A festival may be considered as the cultural resources of an area that make realizable the successful hosting of festival attendees (Oteng-Yeboah,2005). One of the key characteristics of the celebration of a festival is the sense of community created. Festivals and cultural events provide and create a forum for cultural values and traditionsand shared purpose. It also provide a unique opportunity for cultural and social development

African communities hold religion in high esteem and as such religious values are not downplayed in all sectors. Africans wherever believe in the existence of a Supreme Being who it is believed is all seeing but invincible. This Supreme all seeing omnipotent Being is believed to hold the existence of the soul and life of humans. Some Africans in their religions believe in the worship of ancestors with the belief thatthe soul does not die with the body and that there exist good and bad spirits who communicates with the Supreme Being. Religion is linked with all aspects of life the African and even thinks that anything that happens to him has spiritual connotation. Worshiping of ancestors and different deities on different days on different occasions at different settings go on to show that Africans have held on to this faith with hope and in high esteem. Intermediaries, be it fetish priests, diviners, magicians and sorcerers and even soothsayers have helped to mediate between The Supreme Being and mortal men and to help shape and streamline human attitudes in the society for a calm free 
life. Political institutions in the African cultural setting begins with the family head. Each cultural setting must have a chief or who rules through the clan heads. Any member of this cultural setting respects and must abide by the rules and regulations set out. The chief of the clan head is the custodian of these rules and regulation and he metes out the appropriate punishment to anyone going against the rules in the community. Any member who is disloyal to the chief is seen as defiant and is banished. In some Akan societies of Ghana, succession the high office of a chief is either hereditary or by what the person has done to advance the continuity of the community. A political value in the context of African belief is totally linked with social, religious and the moral values. People accord serious respect and total obedience their clan political systems and sometimes their leaders and hold dear political values. Aesthetic values are what inform a people's art, artefacts and crafts which affects their sense of all that is beautiful ion their culture as against what is not beautiful. These aesthetic values of a community affect the artists and his endeavour to produce aesthetically objects that are more acceptable to the cultural setting or the community where he lives. People in their free times try to create and produce admirable objects valuable to them and immensely rich taking source material from around their environment. African rich valuable symbolic meanings are brought to bear in these artworks. It may the production of cloths, sandals, stools, linguist staffs, braiding of the hair, incisions on the body, and mural drawings on walls and among other things as is done in some Ashanti communities. Most of the time, the economic values of the African traditional communities are linked with social cooperation which is mainly associated with the traditional values of farming and fishing. Community members, that is family, relatives and friends would come together to assist in farming called cooperative farming. This kind of farming does not need any payment as it is voluntary in nature. What members expect is that the same members will go and help him on his farm for the same kind of help when the time comes. The synergic nature of the African communal living provided that two or more individuals may pool material and human resources together to uplift one another in times of need through what in Ghana it is referred to as "nnoboa" In some communities in Ghana also community members also cooperated in building of houses and did other positive projects for their fellow members in times of difficulties. One can therefore say that the economic values of the African traditional societies and especially the Akans of Ghana were founded on cooperation and hard work.

\section{Conclusion}

African values are very much an integral part of the people's identity which culture defines. The values which people hold are the things that differentiate one cultural oriented people from the other. It seems simply that the definition of culture maintains values that are important for the survival of the people. The constituents of an African community are also important in the quest to identify the importance of rituals and ceremonies. The African system features interdependency and correlation living which gives the African an identity. The communal nature of the African system gives it an identity. The formation of human institutions and the emergence of social values are also predominant in understanding the place of rituals and ceremonies in the community. The social values guide the people to be able to tell what is right from wrong, thus maintaining some sort of social order.

From the discussions on rituals and ceremonies, we can see the importance of rituals and ceremonial activities to help communities find meaning, order, and relationships in their lives. Rituals encompass every aspect of life, from daily practice and annual celebration to significant transitions and crisis in the lives of individuals and communities. The positive dimensions of culture and the synergic nature of society, the conservation of the environment, and the aesthetic production of the arts all offer us an interesting source of happiness and contentment. This protection of the value systems should be encouraged with the basic reason being that, culture provides knowledge, innovation and should be beneficial to the people who owns it in such a way that the custodians of that culture in using it must move on higher level in their developmental agenda. Harmful and negative cultural practices that are inimical to the progressive development of the people should as matter of fact be done away with sine culture is dynamic.

\section{Bibliography}

Adams, D., and Goldbard, A., (2002) Community, culture and globalization. New York, Rockefeller Foundation

Adebolu, O. O. (2016). The Living Dead: Anthropological interpretation of rites of passage in Umuahia and Emure Ekiti. The Journal of Traditions \& Beliefs, 2(1), 1-18.

Agulana, C. (2010). Community and human well- being in an African culture. A Journal of the Humanities \& Social Sciences, 14(3).

Amponsak,.K (1998)Topics on West Africa religion: religious studies. Accra. Adwinsa Publications.

Awedoba., A.K..(2005) Culture and development in Africa with special reference to Ghana. Accra. HSG.

Aziza, R.C, (2001) The Relationship between language use and survival of culture: the case of Umobvo youth. Nigerian Language Studies. Vol. No 4.

Bourgault, L (1998) From ritual to theatre: village based drama for development in Africa. Cited in Ansu 
Kyereme (1998) Perspectives in indigenous communication in Africa. Vol 1.Theory and applications. Ghana. School of CommunicationsStudies.

Etuk, U, A., (2002) Religion and cultural identity. Ibadan. Hope Publications.

Fafunwa, A, B., (1974) History of education in Nigeria. London. George Allen Unwin.

Kyalo, M. P. (2013) Initiation rites and rituals in African cosmology. International Journal of Philosophy and Theology (1), 34-46.

Geertz, C. (1973) The interpretation of culture. New York .Basic Books.

Getz, D., (1997) Festivals special events and tourism. New York . Cognixant.

Gyekye, K.,(2005) Culture,religion and the pursuit of science. Ghana . NCTE.

Lassiter, J. E, (2000). African culture and personality: Bad social science, effective social activism, or a call to reinvent ethnology. African Studies Quarterly, 3(3), 1-21.

Manu, A. (2003). Africana Studies: the five major African initiation rites. Retrieved from http://www.manuampim.com/africaninitiationrites.htm

Mbiti, J. S. (1990). African religions \& philosophy. Kenya. Heinemann

Ogbujah, C. (2014). African cultural values and inter-communal relations: the case with Nigeria. Developing Countries Studies, 4,208- 217.

Omigbule, M. B. (2017). Rethinking African indigenous ritual festivals, Interrogating the concept of African ritual Drama. African Studies Quarterly, 17(3)

Oteng-Yeboah, A.,(2005) Research and sustainability of the environment and natural rsources. London. Earth Scan Publications.

Rappaport, R. A. (1999). Ritual and religion in the making of humanity (vol. 110). Cambridge University Press.

Sieber, R.(1987) African art in the cycle of life. Philadelphia.Temple University Press,

Sarpong, S. O. (2003). Examining the concept of participation in traditional Societies: A case of the Akan traditional society of Ghana. (Unpublished master's thesis). University of Massachusetts Amherst. Retrieved fromhttps://scholarworks.umass.edu/cie capstones

Taylor, E, B., (1871) Primitive culture: researches into the development of mythology,philosophy religion, language, art and custom. $2^{\text {nd }}$ Ed. London Murray.

Turner, V. (1982) From ritual to theatre. New York: Performing Arts Association.

Turner, V \& Turner E. (1988) Performing ethnography. Drama review. 26(2):33-50.s

Turner, V. (1973). Symbols in African rituals.Science Review, 179(4078), 1100-1105. 